\title{
ANALYSIS OF DYNAMIC CHANGING OF RADIOLOGICAL PICTURE OF PERIAPICAL ODONTOGENIC PROCESSES OF THE JAWS AFTER DIFFERENT METHODS OF DENTAL TREATMENT
}

\author{
Tarasenko S.V., Serova N.S., \\ Shamanaeva L.S., Zagorskij S.V., Diachkova E.Yu.
}

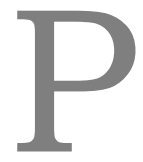

urpose. To assess dynamic changes of radiological picture of periapical odontogenic processes after various methods of dental treatment - endodontic and surgical - to predict long-term results.

Materials and methods. A total of 10 patients with periapical odontogenic processes of the jaws were treated on the basis of the Institute of dentistry of Sechenov University for 2 years from 2016 to 2018: 5 (50\%) underwent endodontic treatment and 5 (50\%) carried on operations. Radiological methods were provided before intervention, in the process (during dental canal treatment), in 6 and 12 months after manipulations.

Results. Analyzed obtained research data were revealed positive effect of both methods -endodontic and surgical - for clinical and X-ray regression of the inflammatory focus, alike an increasing of bone density with a reduction of the discharge zone according to radiological examination in 6 months in all 10 cases $(100 \%)$, the complete disappearance of the focus and the achievement of a density equal to the intact surrounding bone in 8 patients $(80 \%)$.

The absence of $100 \%$ positive long-term results in the treatment of periapical odontogenic processes in dentistry concerns both endodontic and surgical procedures because of the first is not always possible completely to eliminate the focus of infection, and the latter are associated with the presence of general operational risk and do not guarantee the duration of a positive outcome.

Conclusion. Radiological method of examination plays important role in assessing of dynamic changes in the affected periapical area after dental treatment, along with clinical examination.

Keywords: computer tomography, periapical odontogenic processes, endodontic treatment, microscope, cystectomy, osteoplastic material.computer tomography, periapical odontogenic processes, endodontic treatment, microscope, cystectomy, osteoplastic material.

Corresponding author: Diachkova E.Yu., e-mail: secu2003@mail.ru.

For citation: Tarasenko S.V., Serova N.S., Shamanaeva L.S., Zagorskij S.V., Diachkova E.Yu. Analysis of dynamic changing of radiological picture of periapical odontogenic processes of the jaws after different methods of dental treatment. REJR 2019; 9 (1):27-33.

DOI:10.21569/2222-7415-2019-9-1-27-33.

Received: $\quad 14.08 .18 \quad$ Accepted: 20.09 .18 


\title{
АНАЛИЗ АИНАМИЧЕСКИХ ИЗМЕНЕНИЙ РЕНТГЕНОЛОГИЧЕСКОЙ КАРТИНЫ ПЕРИАПИКААЬНЫХ ОАОНТОГЕННЫХ ПРОЦЕССОВ В ЧЕАЮСТЯХ ПОСАЕ РАЗАИЧНЫХ МЕТОАОВ СТОМАТОАОГИЧЕСКОГО АЕЧЕНИЯ
}

\author{
Тарасенко C.B., Серова Н.С., \\ Шаманаева А.С., Загорский С.В., Аьячкова Е.Ю.
}

Ц

ель исследования. Оценить в динамике изменения рентгенологической картины периапикальных одонтогенных процессов после разцичных методов стоматологического мечения - эндодонтического и хирургического - дАя прогнозирования отдаленных результатов.

Материалы и методы. На базе кафедр и клиник Института стоматологии Первого МГМУ имени И.М.Сеченова в течение 2 мет с 2016 по 2018 гг. бымо пролечено 10 пациентов с периапикальными одонтогенными процессами челюстей, 5 (50\%) из которых провели эндодонтическое мечение, а 5 (50\%) - хирургическое, в объеме зубосохраняющих операций. Аучевые методы исследования проводили до стоматологического вмешательства, в процессе мечения (при пролечивании каналов зубов), через 6 и 12 месяцев после мечения в обеих группах.

Результаты. В результате анализа полученных данных было выявлено, что после обоих методов цечения - как эндодонтического, так и хирургического - происходит регрессия воспалительного очага с уменьшением его объема, увеличением плотности костной ткани в данной области со снижением зоны разряжения по данным мучевых методов исследования в течение 6 месяцев после мечения во всех 10 случаях (100\%), полное исчезновение очага и достижение плотности, равной интактной окружающей кости у 8 пациентов (80\%).

Отсутствие $100 \%$ положительных отдаленных результатов при мечении периапикальных одонтогенных процессов в стоматологии касается как эндодонтических, так хирургических манипуляций, так как при эндодонтических операциях не всегда удается устранить полностью очаг инфекции, а хирургические манипуляции сопряжены с наличием общеоперационных рисков и не гарантируют длительность положительного исхода.

Заключение. Одну из главных ролей в оценки динамических изменений в области зоны поражения после проведенных манипуляций в периапикальной области в стоматологии, наряду с клиническим осмотром, играет цучевой метод исследования во всем его многообразии.

Ключевые слова: компьютерная томография, периапикальные одонтогенные процессы, эндодонтическое мечение, микроскоп, цистэктомия, костнопластический материал.

Контактный автор: Дьячкова Е.Ю., e-mail: secu2003@mail.ru

Для иитирования: Тарасенко С.В., Серова Н.С., Шаманаева А.С., Загорский С.В., Дьячкова Е.Ю. Анализ динамических изменений рентгенологической картины периапикальных одонтогенных процессов в челюстях после различных методов стоматологического лечения. REJR 2019; 9 (1):27-33. DOI:10.21569/2222-7415-2019-9-1-27-33.
Статья получена:
14.08.18
Статья принята:
20.09.18

ФГАОУ ВО Первый МГМУ им. И.М. Сеченова Минздрава России (Сеченовский Университет). г. Москва, Россия. 


\section{I} ntroduction.

In dentistry, periapical inflammatory odontogenic processes are characterized by the presence of a permanent focus of infection and are accompanied by periodic episodes of exacerbation of different intensity, which over time leads to loss of teeth, as well as the possible development of a diffuse purulent process involving both bone and soft tissues of the maxillofacial area [1]. The x-ray picture of such processes outside the stage of exacerbation indicates the presence of a zone of bone tissue rarefaction at the apexes of the dental roots, as a rule, of the round shape [2]. With the spread of the inflammatory process, there is an increasing of the volume and zone of reduction of the bone density of the jaw. After various provided dental methods of treatment of periapical odontogenic processes, regression of foci of infection with a change in the $\mathrm{x}$ - ray pattern is possible or, conversely, as a result of the insignificant efficiency of the used techniques, inflammation spreads with the corresponding clinical and radiological picture.

The aim of the study was to assess the dynamics of changes in the radiological picture of periapical odontogenic process after various methods of dental treatment - endodontic and surgical - to predict long-term results.

Materials and methods.

On the basis of departments and clinics of the Institute of dentistry of Sechenov University for 2 years from 2016 to 2018 under the supervision there were 10 patients with periapical odontogenic processes of the jaws. Of these, 5 (50\%) were treated by dentists-therapists (endodontic treatment), and $5(50 \%)$ - by surgery (toothpreserving operations in the volume of resection of the root apex, cystectomy, the use of osteoplastic materials based on hydroxyapatite (radiopaque) and collagen type 1 (non-X-ray contrast). Radiological diagnostic was carried out before the dental intervention, in its process (with the treatment of teeth canals), in 6 and 12 months after treatment in both groups in the volume of intraoral contact radiography of causal teeth on the Digor visiograph, as well as orthopantomography performed on the apparatus "Orthopantomograph 100 "; to plan surgical treatment and prepare the necessary volume of osteoplastic material, conebeam computed tomography was performed in the Vatech and Planmeca systems with the analysis of axial, frontal and saggital projections, as well as $3 \mathrm{D}$ reconstruction of the jaws to analyze the ratio of periapical odontogenic foci with important anatomical structures-canal of inferior alveolar nerve, maxillary sinus and others. The confidence interval, the level of statistical reliability $\mathrm{p}$, the criterion $\mathrm{x} 2$ for four-field tables were calculated for the mathematical evaluation of the reliability of the results.

\section{Results of research.}

As a result of the analysis of the data obtained by us, it was revealed that after both methods of treatment -endodontic and surgical - there is a regression of the inflammatory focus with a decreasing in its volume, an growth of the density of bone tissue in this area with a regression of the discharge zone according to radiological methods in 6 months after treatment in all 10 cases (100\%), the complete disappearance of the focus and the achievement of a density, equal to the intact surrounding bone in 8 patients $(80 \%)$. These results can be related to the initial volume of the process - in the case of full regression it was within $5 \mathrm{~mm}$ in diameter, whereas in the case of incomplete disappearance it exceeded these dimensions ( $p=0.002 ; 20.0 \%$ CI: $6.7 \%-44.5 \%)$. Also it was noted the regression of the clinical picture of chronic inflammation, the absence of episodes of exacerbation during the entire period of observation (2 years). Evaluation of the dynamics of the $\mathrm{x}$ - ray pattern was difficult in the group of patients after surgical treatment in the case of the use of osteoplastic material based on hydroxyapatite due to its initially high density, exceeding or equal to the surrounding intact bone tissue ( 2 cases-40\%).

To demonstrate the results of our study, we give clinical examples.

\section{treatment). \\ Clinical case 1 (group 1 - conservative}

In the clinic patient S., 35 years, came with complaints of pain in the tooth.

Complaints: swelling in the lower jaw on the left, persistent aching pain and pain during chewing solid food.

Examination: the presence of a deep carious cavity in the tooth 2.2 , has not been previously treated. According to the transitional fold in the projection of the tooth swelling, sharply painful palpation. Tooth 22 percussion is painful. Enlarged submandibular lymph nodes on the left is present. On the basis of clinical examination and data of the x-ray method, the diagnosis was established: Exacerbation of chronic granulomatous periodontitis of the tooth 2.2 (Fig. 1).

In the process of endodontic treatment, we used the Seiler dental microscope, carefully removed the remnants of filling material, performed machining with Protaper instruments (Dentsply Maillefer) and an antiseptic in canal preparation Regcap (3\% solution of sodium hypochlorite firm Septodont), closed perforation of domestic material Trioxident, temporarily filled canals with calcium drug METAPASTE (Meta Biomed) for a period of two weeks. The results of treatment were also controlled according to the data of ICRG (Fig. 2). 


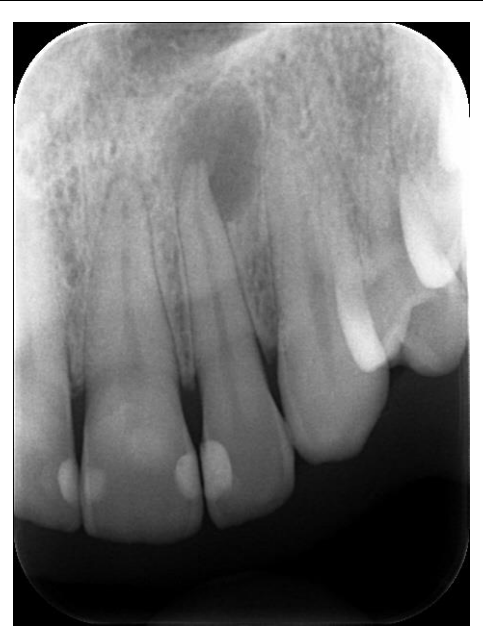

Fig. 1 (Pис. 1)

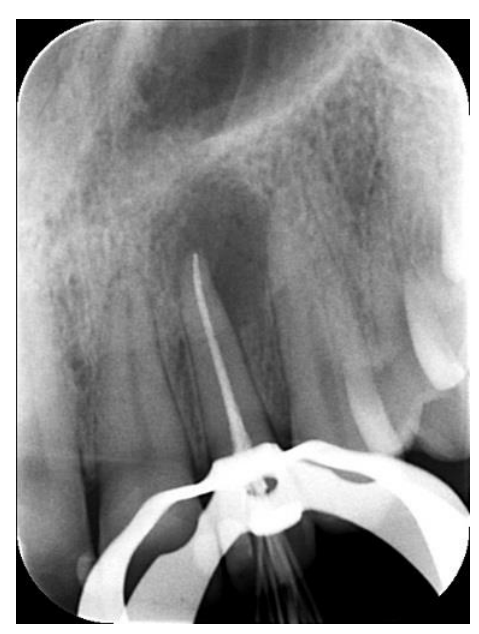

Fig. 2 (Рис. 2)

\section{Fig. 1. Intraoral X-ray.}

Tooth 2.2, there is zone of bone destruction with clear borders closer to nasal cavity in the projection of root apex.

Рис. 1. Внутриротовая контактная рентгенограмма.

Зуб 2.2, в проекции верхушки корня определяется очаг деструкции костной ткани с четкими контурами, примежащий к полости носа.

\section{Fig. 2. Intraoral X-ray.}

Tooth 2.2. There is filling of dental canal with sealing material before root apex without removal in the area of bone rarefaction

Рис. 2. Внутриротовая контактная рентгенограмма.

Зуб 2.2. Визуализируется заполнение канала зуба пломбировочным материалом до верхушки зуба без выведения его в область зоны разряжения костной ткани.

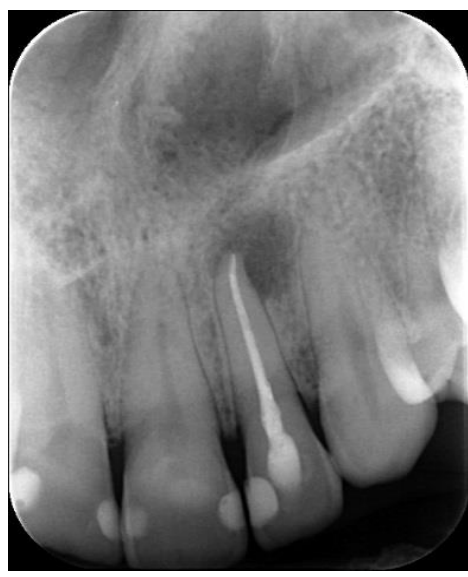

Fig. 3 (Рис. 3)

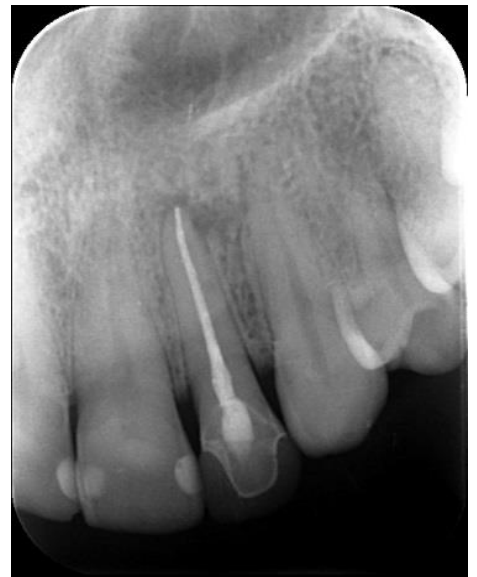

Fig. 4 (Рис. 4)
Fig. 3. Control intraoral contact $x$-ray.

In 2 weeks after patient addressing and beginning of treatment. There is sealing material in 2.2 tooth canal, decreasing of volume of periapical process.

Рис. 3. Контрольная внутриротовая контактная рентгенограмма.

Через 2 недели после обращения пациентки С. и начала цечения. Визуализируется пломбировочный материал в канале зуба 2.2, уменьшение объема периапикального процесса.
Fig. 4. Control intraoral contact x-ray.

In 6 months after patient addressing and beginning of treatment. There is sealing material in 2.2 tooth canal, periapical process is practically not existed, increasing of bone density of its area, presence of structural bone plates.

Рис. 4. Контрольная внутриротовая контактная рентгенограмма.

Через 6 месяцев после обращения пациентки С. и начала мечения. Визуализируется пломбировочный материал в канале зуба 2.2, периапикальный процесс практически не определяется, отмечается увемичение плотности костной ткани в его области, наличие структурированных костных балок. 
After 2 weeks, the channels of the tooth were sealed with guttapercha pins by lateral condensation. The crown part of the tooth was restored with light-cured composite material Charisma Classic, made a control ICRG (Fig. 3). A significant restoration of bone tissue in the periapical zone was determined at the ICRG after 6 months (Fig. 4). The patient no longer complained. ment).

Clinical case 2 (group 2 - surgical treat-

Patient Y. appealed to the clinic of Sechenov University with complaints of discomfort in the tooth 3.6 during biting, mobility of teeth on the lower jaw, inability to eat hard food, bad breath. According to the patient he is an active smoker the gums is hyperemic, edematous, bleeds profusely when probing, identifies pathological toothgingival pockets of a depth of 5-7 $\mathrm{mm}$, purulent discharge, tooth mobility 3.4, 3.6. 3.7, 4.4, 4.5, 4.7 is III-IV degree. The tooth 3.5 was restored with composite material, a temperature test is negative, percussion is positive.

A CT study with 3D reconstruction was conducted. The results revealed generalized resorption of bone tissue of the alveolar part of the mandible vertically and horizontally from $1 / 2$ to $2 / 3$ of the root, furcation defects, in the area of the apexes of the roots of the tooth 3.6 the focus of destruction of bone tissue rounded shape, with clear contours of about $5 \mathrm{~mm}$ in diameter, is visualized,

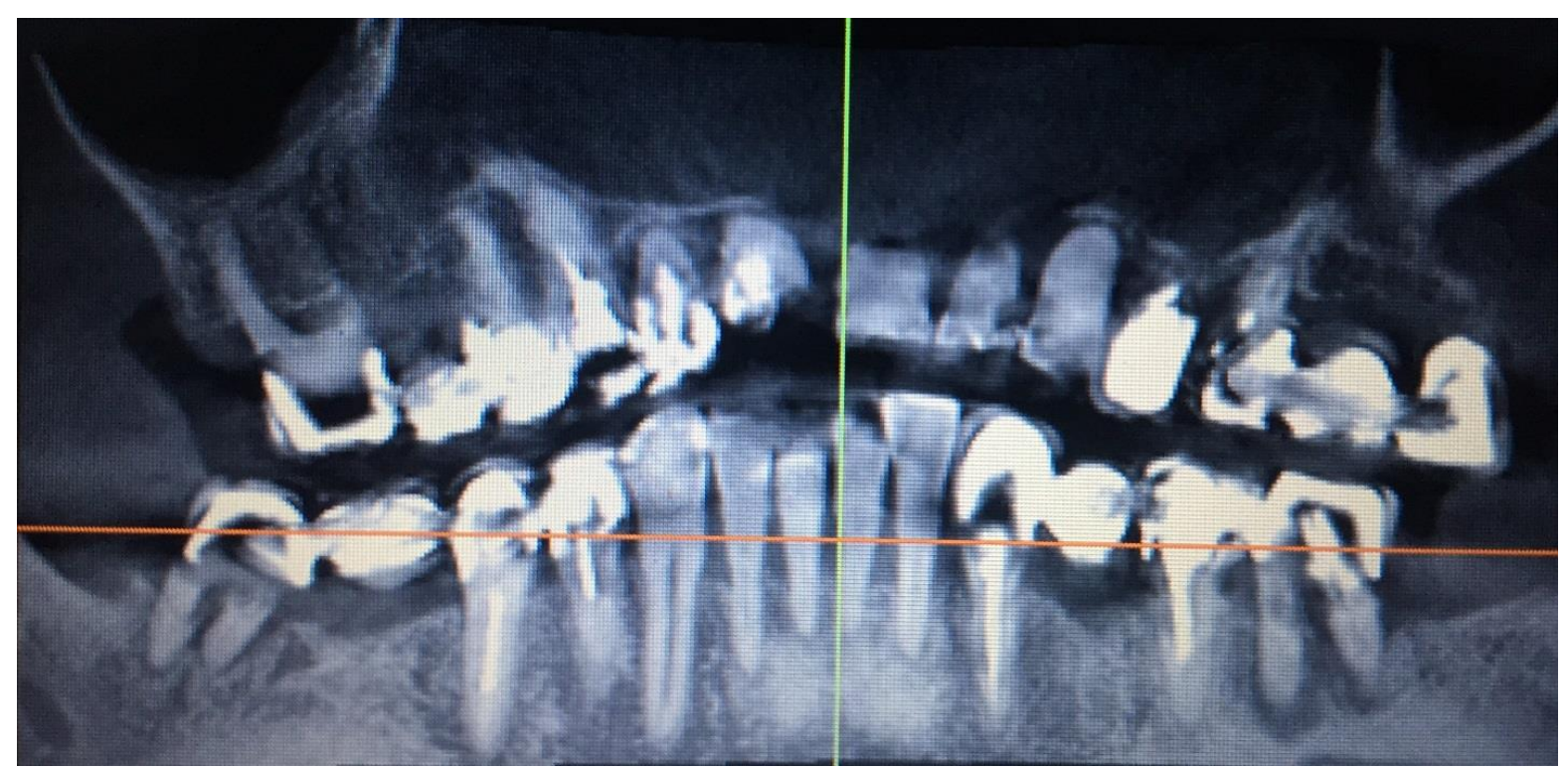

Fig. 5 (Рис. 5)

\section{Fig. 5. Fragment of computer tomography maxilla and mandible of patient $Y$.}

There are periapical areas of bone rarefaction, bone loss more than $1 / 3$ in the projection of teeth 3.4, 3.6. 3.7, 4.4, 4.5, 4.7. There is the presence of zone of decreasing bone density with non-clear borders with circle shape in the projection of absent tooth 3.5 (residual cyst).

\section{Рис. 5. Фрагмент компьютерной томографии верхней и нижней челюсти пациента У.}

Визуализируются периапикальные зоны разряжения костной ткани, ее убыль более, чем на $1 / 3$ в проекции зубов $3.4,3.6 .3 .7,4.4,4.5,4.7$. Отмечается зона сниженной плотности кости с нечетким рисунком округлой формы в проекции отсутствующего зуба 3.5 (резидуальная киста).

(over 1 pack per day), chronic diseases are absent, for a long time lived in the far East, the first signs of the disease appeared there more than 15 years ago, periodically held conservative dental treatment with no apparent lasting results, but in the last 3 years the condition has worsened, tooth mobility increased significantly, there was pain.

At extraoral examination, the configuration of the face is not changed, the skin of the physiological color, is collected freely in the fold; regional lymph nodes are not enlarged. From the side of the mouth: supra - and subgingival dental plaque are in large quantity; the mucous membrane of the outer cortical plate is lysed (Fig. 5). On the basis of the obtained data, the diagnosis "Generalized chronic periodontitis. Chronic periodontitis of tooth 3.6" was obtained, a plan of treatment consisting of conservative management of acute inflammation with subsequent surgical treatment.

On the first stage the patient was prescribed local anti-inflammatory therapy and professional oral hygiene, therapeutic sanitation. Then teeth were removed under local anesthesia 4.7, 4.6, 4.4, $3.4,3.5,3.6,3.7$, the capsule of the radicular cyst 3.6 is completely removed. At the same time, dental implants were installed in the projection of the 


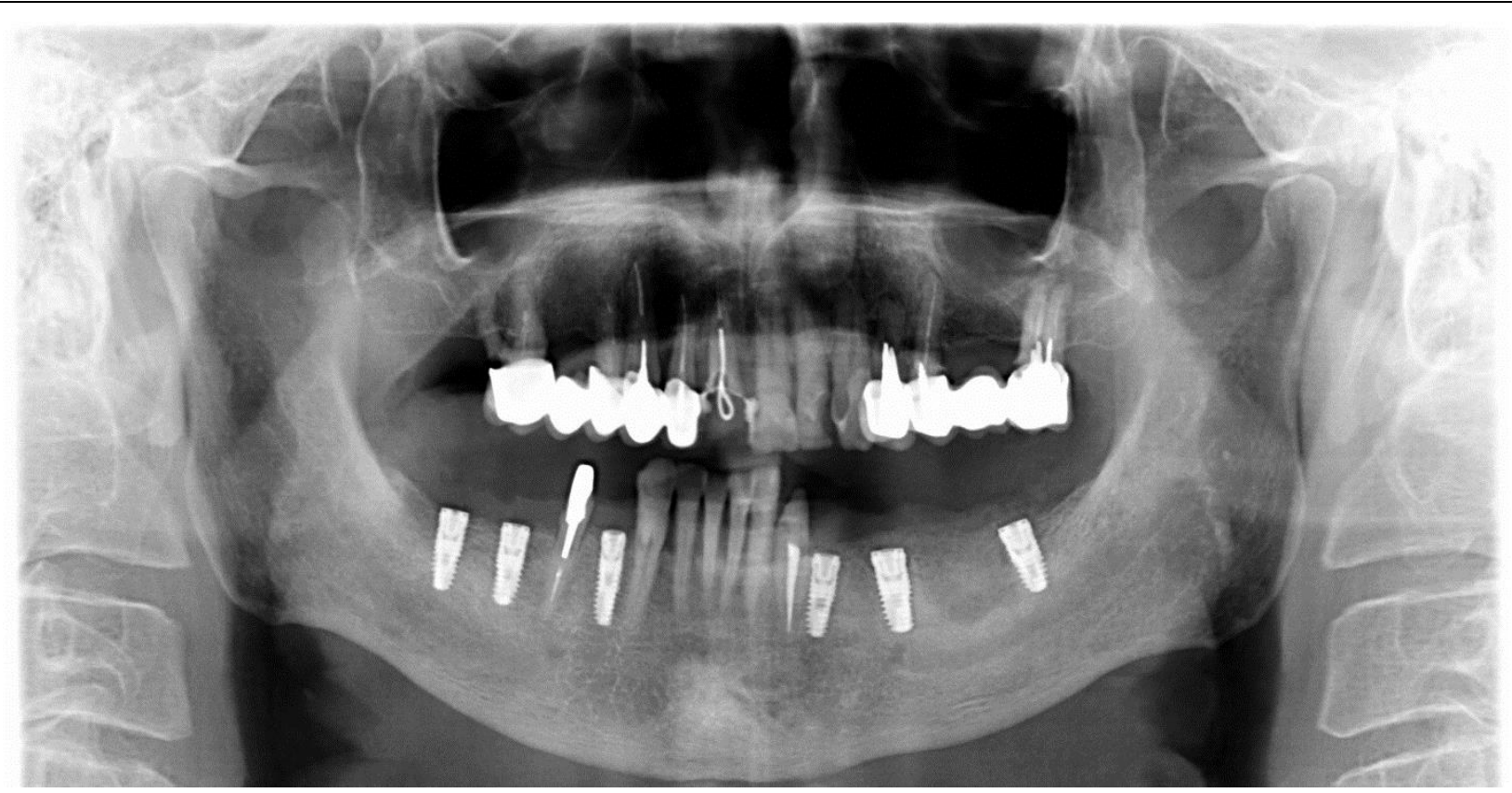

Fig. 6 (Рис. 6)

\section{Fig. 6. Ortopantomogramm of patient $Y$ after surgical treatment (1st day).}

There are inserted implants in the area of removed teeth $3.4,3.5,3.6,3.7,4.4,4.6,4.7$, zone of proved cystectomy.

\section{Рис. 6. Ортопантомограмма пациента У. после провеАения оперативного лечения (1 сутки).}

Визуализируются установленные дентальные имплантаты в области удаленных зубов $3.4,3.5,3.6,3.7,4.4$, 4.6, 4.7, область проведенной цистэктомии.

removed teeth $4.7,4.6,4.4,3.4,3.5,3.7$ using a 3D surgical template, the bone cavity in the 3.6 tooth projection is filled with xenogenic material based on hydroxyapatite (Fig. 6). The postoperative period was relatively calm, there was a partial divergence of sutures in the projection of the tooth 3.5 .

After 6 months, the patient returned to the clinic. A repeated CT study was carried out, the results of which could be judged on the good quality of the newly formed bone tissue in the projection of the tooth 3.6 (Fig. 7). The patient was placed healing abutments on existing implants, as well as a dental implant in the projection of the missing tooth 3.6. At the moment, the patient $Y$. is at the stage of prosthetics.

\section{Discussion.}

Modern technologies used in repeated endodontic treatment allow to achieve a positive result in $75 \%$ of cases. With a high chance of success, re-treatment of the root canals can be carried out in cases where there are no changes in the periapical tissues of the tooth [3].

However, it should be understood that the success of the procedure of repeated endodontic treatment largely determines the qualification of the attending dentist, the availability of appropriate materials, tools and equipment.
It should be borne in mind that the root fracture, mobility of the tooth of III and IV degree, deep pathological pocket and visible cracks of the tooth root are contraindications to repeated endodontic treatment, such teeth must be removed.

Perforation with extensive lesions of the periodontium, such as perforation of the root pin, a strip perforation or resorption of the root belong to the high risk factors when carrying out endodontic treatment.

Treatment periapical odontogenic inflammatory processes in dentistry remains highly controversial, as traditionally carried out in the acute phase of process, existing and approved Protocol of endodontic treatment of teeth often leads to a widening of the focus of infection in the absence of outflow after the sealing of the channels, which leads to the necessity of periosteotomy. In addition, the regression of periapical processes completely and without relapse is possible with full compliance during saving the conditions of septic and antiseptic even at the therapeutic dentistry, following clinical guidelines, and, most importantly, a small volume of the process-usually up to 0.2 $\mathrm{cm}$, and in the absence of a fibrous capsule. The absence of $100 \%$ positive long-term results also applies to surgical procedures - even toothpreserving operations, for example, cystectomy 


\section{RUSSIAN ELECTRONIC JOURNAL OF RADIOLOGY}

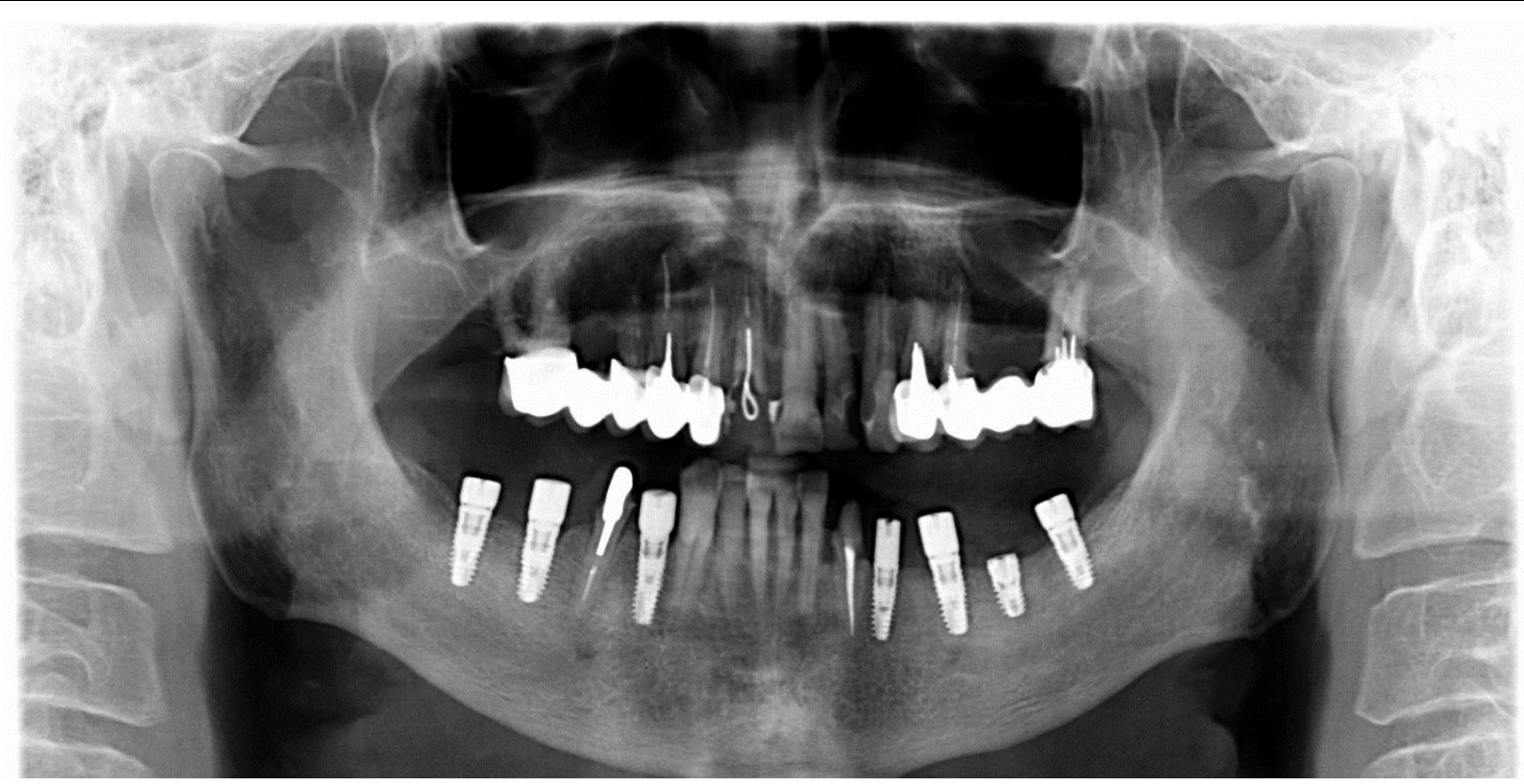

Fig. 7 (Рис. 7)

\section{Fig. 7. Ortopantomogramm of patient $Y$. in 6 months after cystectomy, 3.6 tooth extraction.}

There is increasing of bone structure in the area of early removed 3.6 tooth, expression of bone plates, similarity of density with intact bone tissue of mandible.

Рис. 7. Ортопантомограмма пациента У. через 6 месяцев после цистэктомии, уАаления зуба в позиции 36.

Визуализируется уплотнение костного рисунка в области ранее удаленного зуба 3.6, выраженность костных балок, сходство по плотности с интактной костной тканью нижней челюсти.

and resection of the root apex, are associated with the presence of general operational risk and do not guarantee the duration of a positive outcome $[4,5]$.

\section{Conclusion.}

Thus, the treatment of periapical processes at the reception of a dentist remains a complex issue due to the ambiguity of the results when using both endodontic and surgical techniques, with one of the main roles in assessing of the dynamic changes in the affected area after the ma-

\section{References:}

1. Deepika P., Suma S., Sakshi J., Abhishek D. An Unusual Presentation Of Cutaneous Odontogenic Sinus in Midfacial Region- A Case Series. International Journal of Current Medical And Pharmaceutical Research. 2017; 04 (3): 3146-3148. DOI: http://dx.doi.org/10.24327/23956429.ijcmpr20180413

2. Nohra J., Dagher M., Matni G., Mokbel N., Jobaili E., Naaman N. Effect of Primary Stability and Soft- and Hard-Tissue Thickness on Marginal Bone Loss: A Prospective Pilot Study. Implant Dentistry. 2018. Available at: https://europepmc.org/abstract/med/30188364 (accessed 11.09.2018) DOI: 10.1097/ID.0000000000000810

3. Salehrabi R., Rotstein I. Endodontic treatment outcomes in a large patient population in the USA: an epidemiological study. Journal of Endodontics. 2004; 30 (12): 846-850 nipulation, along with clinical examination, plays a radiological method of research in all its diversity.

\section{Acknowledges.}

All authors were equally involved in the preparation of the material. The investigation was in accordance with the ethical standards of the responsible committee.

Conflict of interest: none declared.

Supported by the "Russian Academic Excellence Project 5-100".

\section{DOI:10.1097/01.don.0000145031.04236.ca}

4. Rahbaran S., Gilthorpe M.S., Harrison S.D., Gulabivala K., Gulabivala K. Comparison of clinical outcome of periapical surgery in endodontic and oral surgery units of a teaching dental hospital: a retrospective study. Oral Surgery, Oral Medicine, Oral Pathology, Oral Radiology, and Endodontics. 2001; 91 (6): 700-709. DOI: 10.1067/moe.2001.114828.

5. Stoyan E.Y., Denysova E.G. Current aspects of odontogenic jaw cysts treatment. Biological Markers in Fundamental and Clinical Medicine. 2017; 11 (3): 41-43. Available at https://biologicalmarker.com/index.php/journal/article/downlo ad/16/13 (accessed 11.09.2018) DOI: 10.29256/01.03.2017.escbm13. 